\title{
Penyakit Crohn: Laporan Kasus
}

\author{
Paul V. Siwy, ${ }^{1}$ Fandy Gosal ${ }^{2}$
}

\author{
${ }^{1}$ PPDS Bagian Penyakit Dalam Fakultas Kedokteran Universitas Sam Ratulangi Manado \\ ${ }^{2}$ Bagian Penyakit Dalam Fakultas Kedokteran Universitas Sam Ratulangi Manado \\ Email: paulsiwy207@gmail.com
}

\begin{abstract}
Crohn's disease is an inflammatory transmural bowel disease with unspecific clinical characteritics. It could involve all parts of the digestive system. The exact cause of this disease remains unknown. Its manifestation depends on the location of involved intestinal mucosa, however, it could also occur extra intestinal. We reported a case of Crohn's disease in a 54-yearold male. In this patient there was defecation with blood in stool, abdominal pain, nausea, and weight loss. Diagnosis was based on history, physical examination, endoscopic examination and colonoscopy, as well as histopathological examination. Colonoscopy EGD examination and tissue biopsy were performed on this patient and revealed esophagitis EGD classification of Los Angeles grade A and erosive gastritis. The results of colonoscopy suggested Crohn's disease, and internal and external hemorrhoids. Pathology examination showed non-specific chronic gastritis, nonspecific chronic ileitis with datia cells, nonspecific pancolitis, and specific chronic proctitis. Disease activity measured by using CDAI (Crohn Disease Activity Index) score was 170 (mild disease). Moreover, based on the Montreal classification it was classified as A3 L3 B1 and SESCD (Simple Endoscopic Scoring System in Crohn's Disease) with value of 0 (not active). This patient was planned to be treated with $500 \mathrm{mg}$ of mesalazine three times daily.
\end{abstract}

Keywords: Crohn's disease

\begin{abstract}
Abstrak: Penyakit Crohn adalah bagian dari penyakit inflamasi saluran cerna dengan karakteristik klinis yang tidak jelas, transmural, dan dapat mengenai semua bagian saluran cerna. Sampai saat ini etiologinya belum diketahui pasti. Manifestasi penyakit ini bervariasi tergantung kerusakan dari lokasi mukosa intestinal yang terkena. Manifestasi ini dapat juga terjadi di luar sistem saluran cerna. Kami melaporkan suatu kasus penyakit Crohn pada seorang laki-laki berusia 54 tahun. Pada pasien ini didapatkan buang air besar disertai darah, nyeri perut, mual dan penurunan berat badan. Diagnosis ditegakkan berdasarkan anamnesis, pemeriksaan fisik, pemeriksaan endoskopi dan kolonoskopi serta pemeriksaan histopatologik. Pemeriksaan EGD-kolonoskopi dan biopsi jarringan dengan hasil EGD esofagitis klasifikasi Los Angeles grade A dan gastritis erosiva. Hasil kolonoskopi ialah kesan suspek penyakit Crohn dengan hemoroid interna dan eksterna. Hasil histopatologi mendapatkan gastritis kronik non spesifik, ileitis kronik non spesifik dengan sel datia, pankolitis non spesifik dan proktitis kronik non spesifik. Aktivitas penyakit diukur dengan skor CDAI sebesar 170 (aktivitas ringan) dan berdasarkan klasifikasi Montreal diklasifikasikan sebagai A3 L3 B1 dan SES-CD sebesar 0 (tidak aktif). Pasien ini direncanakan untuk diterapi dengan pemberian mesalasin 500mg tiga kali sehari.
\end{abstract}

Kata kunci: penyakit Crohn

\section{PENDAHULUAN}

Penyakit Crohn adalah kondisi peradangan kronik, terus menerus, yang dapat memengaruhi saluran cerna di semua bagian dari mulut sampai anus. ${ }^{1}$ Penyakit Crohn adalah peradangan kronis dari dinding usus yang biasanya melibatkan bagian bawah dari usus kecil, bagian atas dari usus besar, atau keduanya tetapi dapat memengaruhi setiap bagian dari saluran cerna. ${ }^{2}$ Penyakit 
ini merupakan bagian dari penyakit peradangan kronik usus (chronic inflammatory bowel disease) yang terdiri dari penyakit Crohn (PC), kolitis ulserativa dan tipe campuran (undeterminate). ${ }^{3}$

Penyakit Crohn dapat terjadi di semua usia, dengan puncak kejadian di usia 30 sampai 40 tahun; tidak terdapat perbedaan bermakna antara laki-laki dan perempuan. ${ }^{3}$ Angka insidensi tahunan per 100.000 orang untuk penyakit Crohn berturut-turut di Eropa ialah 12,7; Asia 5; Amerika Utara 20,2; dan Austalasia 17,4. Prevalensi paling banyak terjadi di area urban daripada rural, dan negara maju lebih banyak daripada negara berkembang. ${ }^{4}$ Data mengenai penyakit Crohn di Indonesia sangat minim dan prevalensi berdasarkan data hasil endoskopi awal tahun 2008, di seluruh rumah sakit di Indonesia berkisar antara $1-3,3 \% .^{3}$

Sampai saat ini belum diketahui etiologi penyakit Chron yang pasti. Banyak mediator inflamasi yang telah diidentifikasi pada penyakit Crohn. Mediator-mediator tersebut memiliki peran penting pada patologi dan karakteristik klinis penyakit ini. Sitokin yang dikeluarkan oleh makrofag karena respon daripada berbagai rangsangan antigenik, berikatan dengan reseptor-reseptor yang berbeda, kemudian menghasilkan efek-efek autokrin, parakrin, dan endokrin. ${ }^{5,6}$ Penyakit Crohn ditandai oleh meningkatnya rekrutmen dan retensi makrofag efektor, neutrofil, dan sel $\mathrm{T}$ ke dalam bagian intestinal yang terinflamasi; sel-sel ini akan diaktivasi dan mengeluarkan sitokin proinflamasi. ${ }^{6,7}$ Beberapa faktor lingkungan seperti perokok aktif, infeksi perut pada bayi, keadaan sosioekonomi yang baik, serta hidup di negara maju daripada negara berkembang ternyata juga dapat meningkatkan kejadian penyakit ini. ${ }^{6}$

Manifestasi penyakit Crohn bervariasi tergantung kerusakan dari lokasi mukosa intestinal yang terkena. Bila terjadi di mukosa usus halus dapat menyebabkan maldigesti dan malabsorbsi sedangkan bila terjadi di ileus terminalis, akan terjadi kelainan reabsorbsi dari asam empedu, yang dapat menyebabkan manifestasi diare sampai konstipasi. ${ }^{8}$ Manifestasi ini dapat terjadi di luar sistem saluran cerna seperti iritis, uveitis, artritis, kolangitis sklerosis primer, dan ankilosis spondilitis. ${ }^{9}$

Tatalaksana penyakit Crohn ini bertujuan untuk mengurangi respon imunologi yang berlebihan, serta mengurangi komplikasi yang dapat ditimbukan. ${ }^{8}$

Berikut ini dilaporkan sebuah kasus seorang pasien dengan penyakit Crohn yang dirawat di Instalasi Rawat Inap Edelweis RSUP Prof. Dr. R. D. Kandou Manado.

\section{LAPORAN KASUS}

Seorang pasien, Tn. AS, 54 tahun, pekerjaan nelayan, suku Sangihe, alamat Bulude, pasien masuk rumah sakit pada tanggal 29 Agusus 2018, selanjutnya dirawat di ruang Edelweis 1 dengan keluhan utama buang air besar disertai darah yang telah dirasakan sejak satu tahun lalu namun hilang timbul. Buang air besar terakhir sebanyak satu kali disertai darah dan cairan dengan volume kurang lebih $10 \mathrm{cc} / \mathrm{kali}$. Pasien juga merasakan nyeri perut sejak dua bulan lalu, dirasakan hilang timbul, dan semakin nyeri pada satu hari sebelum masuk rumah sakit. Nyeri perut dirasakan di perut bagian tengah seperti diiris-iris dan menjalar ke seluruh perut. Pasien juga merasakan mual namun tidak sampai muntah dan ditemukan juga penurunan nafsu makan serta penurunan berat badan kurang lebih 8 $\mathrm{kg}$ dalam setahun ini. Tidak ditemukan riwayat batuk, sesak, maupun demam. Buang air kecil normal. Pasien pernah dirawat di rumah sakit karena mengalami buang air besar disertai darah sebulan yang lalu. Pasien memiliki riwayat kolesterol tinggi dan penyakit darah tinggi sejak lima tahun yang lalu. Pasien mengonsumsi nifedipin namun tidak teratur. Riwayat penyakit diabetes melitus, gangguan jantung, paru, dan penyakit ginjal disangkal. Tidak ada anggota keluarga yang mengalami keluhan serupa. Riwayat mengonsumsi obat-obatan dan jamu disangkal. Pasien tidak memiliki riwayat alergi obat maupun makanan. Riwayat kebiasaan merokok dengan jumlah empat sampai lima batang setiap hari selama 20 tahun ini sedangkan minum alkohol disangkal. Pasien sering mengonsumsi 
daging atau ikan.

Pemeriksaan fisik ditemukan keadaan umum tampak sakit sedang, kesadaran kompos mentis. Tekanan darah 140/80 $\mathrm{mmHg}$, laju nadi 63 kali per menit, laju pernapasan 20 kali per menit, suhu badan $36,5^{\circ} \mathrm{C}$. Berat badan $51 \mathrm{~kg}$, tinggi badan $160 \mathrm{~cm}$, IMT $19,92 \mathrm{~kg} / \mathrm{m}^{2}$ dengan kesan gizi cukup. Pada pemeriksaan kepala didapatkan konjungtiva anemis, sklera tidak ikterik, dan pupil isokor. Tonsil normal dan tidak terdapat peradangan tenggorokan. Di daerah leher tidak ditemukan dilatasi vena; trakea letak di tengah, tidak ditemukan peningkatan tekanan vena jugularis. Pemeriksaan dada tampak simetris, dalam keadaan statis dan dinamis, fremitus paru kiri dan kanan normal, sonor pada paru kiri dan kanan, tidak ada ronkhi maupun wheezing. Pada pemeriksaan jantung, inspeksi ictus cordis tidak terlihat; palpasi ictus cordis tidak teraba; pada perkusi batas kiri jantung pada sela iga IV 1 $\mathrm{cm}$ lateral dari garis mid-klavikula kiri dan batas kanan jantung pada sela iga IV garis sternalis kanan. Bunyi jantung pertama dan kedua dalam batas normal, teratur, tidak ada bising dan galop. Pada pemeriksaan abdomen, inspeksi didapatkan abdomen datar, pada palpasi lemas, terdapat nyeri tekan bagian epigastrium menjalar ke umbilikus, tidak terdapat pembesaran hati dan limpa, tidak teraba massa, ballotement ginjal tidak ada. Pada perkusi didapatkan bunyi timpani dan pada auskultasi bising usus dalam batas normal. Ektremitas hangat, tidak terdapat edema.

Pada pemeriksaan laboratorium didapatkan hasil hemoglobin $11,4 \mathrm{~g} / \mathrm{dL}$, hematokrit $39,5 \%$, eritrosit $5,14 \times 10^{6} \mathrm{sel} / \mathrm{mm}^{3}$, leukosit $12.600 \mathrm{sel} / \mathrm{mm}^{3}$, trombosit 371.000 $\mathrm{sel} / \mathrm{mm}^{3}, \mathrm{MCH} 22,1 \mathrm{pg}, \mathrm{MCHC} 28,8 \mathrm{~g} / \mathrm{dL}$, MCV 76,8 fl, SGOT 13 U/L, SGPT 8 U/L, ureum darah $26 \mathrm{mg} / \mathrm{dL}$, kreatinin darah 0,8 $\mathrm{mg} / \mathrm{dL}$, gula darah sewaktu $76 \mathrm{mg} / \mathrm{dL}$, albumin 3,51 g/dL, klorida 103,7 mEq/L, kalium 3,75 $\mathrm{mEq} / \mathrm{L}$, dan natrium 138 $\mathrm{mEq} / \mathrm{L}$. Hasil pemeriksaan hemostasis ialah PT 13,3 detik, INR 0,98 detik, dan APTT 42,0 detik. Pemeriksaan feses lengkap secara makroskopik feses berwarna kuning, konsentrasi cair, bau busuk, cacing (-); secara mikroskopik eritrosit 6-5/LPB, leukosit 6-8/LPB, epitel 2-3, telur/larva cacing (-), bakteri positif, jamur (-), protozoa (-), benzidin tes (darah samar) $(+)$. Foto toraks didapatkan dalam batas normal. Hasil pemeriksaan elektrokardiografi didapatkan sinus ritme, denyut nadi $60 \mathrm{kali} /$ menit, aksis normal. Berdasarkan anamnesis, pemeriksaan fisik, dan laboratorium, penderita didiagnosis kerja sebagai hematokezia karena curiga hemoroid diagnosis banding keganasan saluran gastrointestinal, hipertensi, dan anemia karena penyakit kronis diagnosis banding keganasan.

Pasien selanjutnya ditatalaksana dengan pemberian infus intravena $\mathrm{NaCl} \quad 0,9 \% \quad 20$ tetes/menit, lansoprazol injeksi $30 \mathrm{mg}$ dua kali sehari secara intravena, asam tranexamat injeksi $500 \mathrm{mg}$ intravena dua kali sehari, dan amlodipin $5 \mathrm{mg}$ setiap pagi hari. Direncanakan diet bubur kecap untuk persiapan tindakan esofagogastro-duodenoskopi (EGD) dan kolonoskopi (4 September 2018).

Pemantauan pada hari ketiga perawatan (tanggal 02/09/2018), buang air besar berdarah sudah tidak dialami pasien. Pada pemeriksaan fisik didapatkan, tekanan darah 110/70 mmHg, laju nadi 88 kali per menit, laju napas 20 kali per menit, dan suhu badan $36,6^{\circ} \mathrm{C}$. Terapi dengan pemberian infus intravena $\mathrm{NaCl}$ 0,9\% 20 tetes/menit, lansoprazol injeksi $30 \mathrm{mg}$ dua kali sehari, dan amlodipin $5 \mathrm{mg}$ setiap pagi hari.

Pemantauan pada hari keempat perawatan (tanggal 03/09/2018), buang air besar berdarah sudah tidak dialami pasien. Pada pemeriksaan fisik ditemukan tekanan darah $120 / 70 \mathrm{mmHg}$, laju nadi 80 kali per menit, laju napas 18 kali per menit, dan suhu badan $36,6^{\circ} \mathrm{C}$. Terapi dengan pemberian infus intravena $\mathrm{NaCl}$ 0,9\% 20 tetes/menit, lansoprazol injeksi $30 \mathrm{mg}$ dua kali sehari dan amlodipin $5 \mathrm{mg}$ setiap pagi hari. Pasien dipersiapkan untuk tindakan esofagogastroduodenoskopi dan kolonoskopi tanggal 4 September 2018 dengan melakukan prosedur klisma, minum laktulose tablet, dan Niflec (larutan Macrogol 4000, $\mathrm{NaSO}_{4}$, $\mathrm{NaHCO}_{3}, \mathrm{NaCl}, \mathrm{KCL}$ ).

Pemantauan pada hari kelima pera- 
watan (tanggal 04/09/2018), keluhan buang air besar berdarah sudah tidak dialami pasien. Tekanan darah 140/90 $\mathrm{mmHg}$, laju nadi 86 kali per menit, laju napas 18 kali per menit, dan suhu badan $36,0^{\circ} \mathrm{C}$. Pasien menjalani pemeriksaan EGD dan kolonoskopi pada jam 09.18 hingga 11.30 dengan simpulan EGD yaitu esofagitis klasifikasi Los Angeles grade A dan gastritis erosiva serta dilakukan biopsi 3 keping: 2 keping di antrum gaster dan 1 keping di corpus gaster. Dilakukan prosedur kolonoskopi dan didapatkan hasil: ileum terminalis tampak hiperemis, terdapat erosi dan pus serta dilakukan biopsi sebanyak 2 keping; sekum tampak hiperemis, terdapat erosi dan pus serta dilakukan biopsi 1 keping; kolon asendens, kolon transversum, kolon desenden dan sigmoid tampak hiperemis, terdapat erosi serta dilakukan biopsi 1 keping tiap segmen; rektum tampak hiperemis, terdapat erosi serta dilakukan biopsi 1 keping dan anus hemoroid interna dan eksterna. Simpulan dari pemeriksaan ini ialah curiga penyakit Chron dengan hemoroid interna dan eksterna. Disarankan untuk diterapi, evaluasi pemeriksaan histopatologik, periksa fecal calprotectin, interferon gamma release assays (IGRAs) dan terapi. Oleh karena dari hasil pemeriksaan kolonoskopi diduga penyakit Crohn, maka dilakukan penghitungan skor CDAI (Crohn's Disease Activity Index) dan didapatkan skor 170 aktivitas ringan. Berdasarkan klasifikasi Montreal kasus ini diklasifikasikan sebagai A3 L3 B1. Selain itu dilakukan skoring dengan Simple Endoscopic Scoring System for Crohn's Disease dan didapatkan skor 0 tidak aktif.

Pemantauan pada hari keenam perawatan (tanggal 05/09/2018), keluhan buang air besar berdarah sudah tidak ada. Tekanan darah 130/80 mmHg, laju nadi 80 kali per menit, laju napas 20 kali per menit, dan suhu badan $37.2^{\circ} \mathrm{C}$. Pasien diijinkan untuk rawat jalan dengan obat pulang lansoprazol $30 \mathrm{mg}$ dua kali sehari dan amlodipin 5mg satu kali sehari. Direncanakan pemeriksaan fecal calprotectin dan pemberian obat mesalasin 500mg tiga kali serta disarankan untuk diet rendah lemak dan kontrol ke Poli Gastro- enterologi RSUP Prof. Dr. R. D. Kandou Manado.

Pada pemeriksaan histopatologik didapatkan bagian antrum terdiri dari kelenjarkelenjar mukosa yang sebagian erosif di antara stroma yang hiperemis dan diinfiltrasi oleh sel-sel limfosit dengan Helicobacter pylori (-); pada jaringan korpus terdiri dari kelenjar-kelenjar mukosa di antara stroma yang diinfiltrasi oleh sel-sel limfosit dengan Helicobacter pylori (-); pada bagian ileum terminalis terdiri dari kelenjar-kelenjar mukosa dengan stroma yang mengandung infiltrat sel limfosit cukup padat dan 1-2 sel datia; pada bagian sekum, kolon asendens, kolon transversum, kolon desendens, sigmoid dan rektum terdiri dari kelenjarkelenjar mukosa diantara stroma yang diinfiltrasi oleh sel-sel limfosit cukup padat dan tidak tampak struktur tuberkel ataupun sel-sel maligna pada sediaan ini. Dari hasil pemeriksaan tersebut didapatkan simpulan gastritis kronik non spesifik, ileitis kronik non spesifik dengan sel datia, pan kolitis non spesifik, dan proktitis kronik non spesifik.

\section{BAHASAN}

Penyakit Crohn adalah bagian dari penyakit inflamasi saluran cerna dengan karakteristik klinis yang tidak jelas, transmural, dan dapat mengenai semua bagian saluran cerna dari mulut sampai anus; ditentukan berdasarkan lokasinya (seperti ileum terminalis, kolon, ileum, dan saluran cerna bagian atas) serta pola dari penyakitnya (inflamasi, fistula, atau striktur). ${ }^{10}$

Insiden penyakit Crohn pada ras kulit putih kira-kira lebih tinggi empat kali lipat dibandingkan ras lainnya. Penyakit Crohn ini paling sering didiagnosis pada usia dewasa muda. Insiden paling tinggi dan mencapai puncaknya pada usia 15-40 tahun, kemudian yang berusia 55-65 tahun. Sekitar $10 \%$ dari pasien dengan penyakit Crohn berusia kurang dari 18 tahun. Berdasarkan statistik internasional, insiden penyakit Crohn sekitar 2,2-14,3 kasus per 100000 orang per tahun untuk kolitis ulseratif dan 3,1-14,6 kasus per 100000 orang per tahun untuk penyait Crohn. Insidens di negara Amerika Serikat, Inggris, dan Skandinavia 
lebih tinggi jika dibandingkan dengan negara Eropa, sedangkan di negara Asia dan Afrika insidensnya rendah. ${ }^{11}$ Di negara Amerika Serikat terdapat 3-5 kasus per 100.000 jiwa setiap tahunnya. Jenis kelamin perempuan lebih sering mengalami penyakit ini dibandingkan laki-laki. ${ }^{8,11}$ Di Amerika penyakit Crohn terjadi 3-5 kali lebih tinggi pada orang Yahudi dibandingkan dengan bukan Yahudi. Pada kasus ini, didapatkan laki-laki berusia 54 tahun, warga negara Indonesia, suku Sangihe, dengan pekerjaan nelayan.

Etiologi sebenarnya dari penyait Crohn belum pasti. Terdapat penelitian yang memerkirakan teori etiologi dari penyakit Crohn, yaitu infeksi spesifik yang persisten, disbiosis (ratio abnormal daripada agen mikroba yang menguntungkan dan komensal yang merugikan), fungsi barier mukosa yang terganggu, dan clearance mikroba yang terganggu. ${ }^{12,13}$ Faktor-faktor pencetus yang memungkinkan terjadinya aktivasi respon imun pada penyakit Crohn ialah organisme patogenik (yang belum dapat diidentifikasi), respon imun terhadap antigen intraluminal (contohnya protein dari susu sapi), atau suatu proses autoimun dimana ada respon imun yang sesuai terhadap antigen intraluminal, adapula respon yang tidak sesuai pada antigen yang mirip yang terjadi pada sel epitel intestinal (contohnya perubahan fungsi barrier). Menurut studi prospektif E3N, ditemukan bahwa makanan dengan protein hewani yang tinggi (daging atau ikan) berhubungan dengan meningkatnya risiko terjadi penyakit Crohn. ${ }^{14}$ Penderita penyakit Crohn mungkin memiliki predisposisi genetik terhadap penyakit ini. Beberapa penelitian menemukan kromosom 16 (gen IBD1), yang akhirnya menyebabkan teridentifikasinya gen NOD2 (yang saat ini disebut CARD15) merupakan gen pertama yang secara jelas beruhubugan dengan penyakit Crohn. Juga terdapat penelitian yang mendapatkan kromosom 5 (5q31) dan 6 (6p21 dan 19p) sebagai gen yang dicurigai ada hubungannya dengan penyakit Crohn. Sebagai simpulan, dari semua gen-gen yang berpotensial ini dikatakan bukan penyebab (kausatif) daripada penyakit Crohn, namun gen-gen ini mendukung untuk terjadinya penyakit Crohn (permisif). ${ }^{14}$ Merokok akan meningkatkan risiko terjadinya penyakit Crohn tetapi bersifat protektif terhadap timbulnya kolitis ulseratif. Pada kasus ini, pasien dengan pekerjaan nelayan yang sering mengonsumsi daging atau ikan dan sering merokok sebanyak 4-5 batang sehari selama 20 tahun ini.

Manifestasi klinis penyakit Crohn bervariasi dari yang ringan sampai berat selama kondisi relaps, atau bisa berkurang bahkan hilang selama remisi. Gejala juga bergantung pada lokasi saluran cerna yang terkena. Manifestasi klinis dibedakan menjadi tiga, yaitu manifestasi umum, seperti demam, penurunan nafsu makan, penurunan berat badan, lemah badan, keringat malam, retardasi mental, dan amenorea; manifestasi intestinal seperti diare, buang air besar berlendir sampai berdarah, diare malam hari, dan inkontinensia, konstipasi sampai obstruksi, nyeri perut sampai kram, tenesmus, mual dan muntah; serta manifestasi ekstraintestinal seperti manifestasi sendi (artropati perifer), manifestasi kulit (eritroderma nodosum, pioderma gangrenosum), manifestasi mata (skleritis, episkleritis, uveitis), manifestasi hepatobilier (kolangitis sklerosis primer). ${ }^{4,11}$ Selain itu berdasarkan lokasi lesi yaitu di ileum terminalis, sering menimbulkan manifestasi klinis obstruksi sampai kondisi sepsis yang dicurigai adanya kondisi perforasi atau adanya abses dengan atau tanpa fistula, yang biasanya pada $40 \%$ kasus membutuhkan tindakan pembedahan. Penyakit Crohn pada kolon juga dapat terjadi pada sebagian segmen atau seluruh kolon, dan sering sulit dibedakan dengan kolitis ulseratif, akibatnya diklasifikasikan dalam kondisi kolitis yang tidak dapat ditentukan (undeterminate colitis). ${ }^{10}$ Pada pasien ini manifestasi utama ialah buang air besar disertai darah yang dirasakan sejak satu tahun lalu namun hilang timbul. Buang air besar terakhir sebanyak satu kali disertai darah dan cairan dengan volume \pm 10 cc tiap kali buang air besar. Pasien juga merasakan nyeri perut dirasakan hilang timbul sejak dua bulan terakhir, 
semakin nyeri pada satu hari sebelum masuk rumah sakit. Nyeri perut dirasakan di perut bagian tengah seperti diiris-iris menjalar ke seluruh perut. Pasien juga merasakan mual namun tidak sampai muntah dan ditemukan juga penurunan nafsu makan serta penurunan berat badan kurang lebih $8 \mathrm{~kg}$ dalam setahun ini.

Diagnosis peyakit ini ditentukan dengan anamnesis gejala klinis, riwayat keluarga dengan penyakit ini, serta pemeriksaan fisik dan pemeriksaan penunjang laboratorium, endoskopi serta pemeriksaan patologi anatomi. ${ }^{10,15}$

Tindakan endoskopi merupakan prinsip utama dalam pengelolaan pasien dengan penyakit inflamasi saluran cerna terutama dalam mendiagnosis dan menentukan tatalaksana penyakit Crohn. Manfaat dari endoskopi ialah sebagai penentu diagnosis awal, membedakan penyakit Crohn dengan kolitis ulseratif (89\% kasus), menentukan lokasi lesi dan aktivitasnya, serta monitor respon dari terapi. Kolonoskopi dapat memberikan gambaran visual langsung terhadap mukosa dari rektum, kolon, dan ileum terminal dengan efek samping yang minimal. Idealnya ialah mengambil sampel biopsi sebanyak 2 sampel dari 6 lokasi sepanjang kolon termasuk rektum dan ileum terminalis. Pemeriksaan endoskopi pada penyakit Crohn menunjukkan adanya gambaran kolitis segmental atau skip lesions, tidak adanya lesi di rektum, sebagian besar lesi di ileum terminalis, adanya gambaran saluran fistula, dan penyakit anal maupun perianal. Selain itu bisa juga terdapat gambaran ulserasi maupun cobble stone. Ileitis yang berat atau terlihat pada tidak adanya pankolitis harus dicurigai ke arah penyakit Crohn. Temuan patologik juga disesuaikan dengan usia, dimana pada usia tua lesi lebih banyak di lokasi kolon dan usus distal dibandingkan dengan usia muda yang banyak terjadi di ileocolic junction. ${ }^{16}$ Pemeriksaan endoskopi pada pasien ini didapatkan esofagitis klasifikasi Los Angeles grade A dan gastritis erosiva. Kolonoskopi menunjukkan adanya hiperemis, erosi serta pus yang terdapat di ileum terminalis dan sekum. Pada kolon asenden, transversum, desendens, sigmoid sampai rektum terdapat gambaran hiperemis dan erosi, anus ditemukan hemoroid interna dan eksterna dengan simpulan curiga penyakit Crohn, hemoroid interna dan eksterna.

Pemeriksaan histopatologik penyakit Crohn menunjukkan adanya gambaran granuloma (kumpulan sel monosit atau makrofag, dan sel inflamasi lain seperti limfosit, dengan atau tanpa giant cells) pada lapisan lamina propria epitel saluran cerna, submukosa, sampai lapisan serosa. ${ }^{17}$ Akan tetapi gambaran granuloma ini tidak patognomonis untuk penyakit Crohn (ditemukan hanya 50-60\% saja dari keseluruhan pemeriksaan biopsi jaringan dari endoskopi), karena dapat ditemukan pada kolitis ulseratif, serta penyakit kronis inflamasi lain seperti tuberkulosis usus, sarkoidosis, dan kolitis terkait obat. Kesulitan diagnosis secara histopatologik dapat terjadi pada kasus kolitis fulminan, onset awal dari penyakit, dan pada penyakit yang sudah berlangsung lama. ${ }^{18,19}$ Diagnosis presumtif untuk menentukan penyakit Crohn pada pemeriksaan histopatologik dengan adanya granuloma epiteloid dan salah satu dari gambaran kerusakan epitel atau respon inflamasi seluler yang berupa peningkatan intesitas serta perubahan komposisi dan distribusi sel inflamasi; atau setidaknya terdapat 3 (tiga) gambaran perubahan sel inflamasi di lapisan sel yang normal, gambaran skip lessions, dan distorsi serta hilangnya bagian dari kripta mukosa saluran cerna, jika tidak ditemukan adanya granloma epitel. ${ }^{20}$ Pemeriksaan histopatologik mendapatkan pada bagian antrum terdiri dari kelenjar-kelenjar mukosa yang sebagian erosif diantara stroma yang hiperemis dan diinfiltrasi oleh sel-sel limfosit dengan Helicobacter pylori (-); pada jaringan korpus terdiri dari kelenjarkelenjar mukosa diantara stroma yang diinfiltrasi oleh sel-sel limfosit dengan Helicobacter pylori (-); pada bagian ileum terminalis terdiri dari kelenjar-kelenjar mukosa dengan stroma yang mengandung infiltrat sel limfosit cukup padat dan satu sampai dua sel datia; pada bagian sekum, kolon asendens, kolon transversum, kolon 
desendens, sigmoid dan rektum terdiri dari kelenjar-kelenjar mukosa diantara stroma yang diinfiltrasi oleh sel-sel limfosit cukup padat dan tidak tampak struktur tuberkel ataupun sel-sel maligna pada sediaan ini; dari hasil pemeriksaan tersebut didapatkan kesimpulan gastritis kronik non spesifik, ileitis kronik non spesifik dengan sel datia, pan kolitis non spesifik, proktitis kronik non spesifik.

Pemeriksaan lain yang dapat digunakan dalam diagnosis ialah pemeriksaan fecal calprotectin yang meruoakan protein sitosol dalam neutrofil granulosit serta makrofag, monosit, dan sel epitel. Jika terjadi inflamasi pada saluran cerna seperti pada kasus penyakit usus inflamasi (inflammatory bowel disease) yang aktif makan, sel PMN neutrofil akan bermigrasi dari sirkulasi ke dalam sel mukosa intestinal yang mengalami peradangan. Dengan bermigrasinya sel PMN ke dalam lumen intestinal maka protein proinflamasi seperti penyait Crohn dapat dideteksi dan diukur dalam feses. Berdasarkan the Buhlmann Calprotectin Assay, dikatakan normal bila $<50 \mu \mathrm{g} / \mathrm{dL}$, penyakit ringan bila $50-200 \mu \mathrm{g} / \mathrm{dL}$, dan penyakit aktif bila $>200 \mu \mathrm{g} / \mathrm{dL} .{ }^{21}$ Pada pasien ini direncanakan untuk diperiksa tetapi pasien tidak balik lagi untuk kontrol lagi ke Poli Gastroenterologi RSUP Prof. Dr. R. D. Kandou Manado.

Penyakit ini kemudian diklasifikasikan berdasarkan klasifikasi Montreal (2005) yang merupakan revisi dari klasifikasi Wina (2001), yang digunakan untuk menentukan subtipe fenotipe dari penyakit ini. Klasifikasi ini didasarkan pada usia (age), yaitu A1 untuk usia di bawah 16 tahun, A2 untuk usia antara 17 sampai 40 tahun, dan A3 untuk usia di atas 40 tahun; lokasi (location), yaitu L1 untuk lokasi di ileum terminalis, L2 untuk lokasi di kolon, L3 untuk lokasi di ileokolon, dan L4 untuk lokasi di saluran cerna bagian atas; karakteristik penyakit (disease behaviour), yaitu B1 tidak striktur dan tidak penetrasi, B2 untuk kasus striktur, dan B3 untuk kasus penetrasi, serta tambahan $\mathrm{P}$ untuk kasus bilamana terjadi komplikasi fistula di perianal. Penyakit ini dapat berubah sewaktu-waktu dan klasifikasi ini digunakan untuk mendeteksi secara dini perubahan dari karakteristik penyakit ini. ${ }^{22}$ Pada pasien ini didapatkan klasifikasi penyakit sebagai A3, L3, B1 dengan arti usia di atas 40 tahun, mengenai ileum terminalis dan kolon dengan karakteristik tidak striktur dan tidak penetrasi.

Aktivitas peyakit ini harus dinilai untuk menentukan tatalaksana yang tepat terhadap penyakit ini. ${ }^{20,23}$ Terdapat beberapa metode penilaian yang dapat dipakai dalam menilai aktivitas secara klinis terhadap penyakit ini, salah satunya dengan Crohn's Disease Activity Index (CDAI), yaitu nilai $<150$ sebagai tidak aktif; 150-219 aktivitas ringan; 220-450 aktivitas sedang; dan $>450$ aktivitas berat. Penilaian meliputi volume, konsistensi, dan frekuensi tinja; penggunaan obat anti motilitas; frekuensi nyeri perut; adanya manifestasi ekstraintestinal seperti artritis atau artralgia, iritis, uveitis; adanya komplikasi fistula atau abses; serta parameter umum lain seperti adanya demam, jenis kelamin, berat badan. ${ }^{24}$ Akan tetapi pada penilaian ini terdapat beberapa keterbatasan, seperti variabilitas penilaian secara subyektif masih tinggi, rendahnya akurasi penilaian pada kasus dengan komplikasi fistula, dan tidak dapat dipakai pada kasus pasca reseksi usus atau adanya stoma. ${ }^{29}$ Oleh karena itu, dapat digunakan penilaian secara endoskopi dengan menggunakan parameter SES-CD (Simple Endoscopy Score for Crohn's Disease) dengan nilai 0-2 untuk kasus inaktif, 3-6 untuk kasus ringan, 7-16 untuk kasus sedang, dan >16 untuk kasus berat. Penilaian dengan SES-CD berguna juga untuk menilai respon terapi dan remisi dari penyakit ini dengan melihat secara langsung proses penyembuhan mukosa sesuai dengan target tatalaksana penyakit ini. ${ }^{26}$ Pada pasien ini didapatkan CDAI (Crohn's Disease Activity Index) skor 170 (aktivitas ringan), dan didapatkan SES-CD (Simple Endoscopic Scoring System for Crohn's Disease) skor 0 (tidak aktif).

Tatalaksana terhadap penyakit Crohn ditentukan dari lokasi lesi, aktivitas dari penyakit ini secara klinis dan histopato- 
logik, serta beratnya derajat dari penyakit ini. ${ }^{23}$ Prinsip tatalaksana penyakit Crohn ialah mengobati kondisi peradangan aktif hingga cepat mencapai remisi, mencegah peradangan berulang dengan mempertahankan remisi selama mungkin, serta mengobati dan mencegah komplikasi yang timbul. ${ }^{27}$ Tatalaksana penyakit ini meliputi tatalaksana umum, tatalaksana farmakologik, dan tatalaksana operatif. Terdapat dua strategi yang dapat dipakai dalam tatalaksana farmakologis yaitu dengan pendekatan "step up" yang dimulai dengan kortikosteroid atau asam 5-aminosalisilat, atau pendekatan "step down" dengan menggunakan agen biologik anti-TNF sebagai terapi inisiasi. ${ }^{23}$ Metode "step down" ini masih kontroversi karena dapat berisiko menyebabkan kanker dan peningkatan kejadian infeksi. ${ }^{28}$ Tatalaksana umum meliputi pemberian antibiotik seperti metronidazol, dan perbaikan kondisi umum pasien, dan tatalaksana nutrisi yang adekuat. ${ }^{27}$ Tatalaksana farmakologik dibedakan berdasarkan aktivitas penyakit, yaitu pada kondisi peradangan aktif dapat diberikan golongan kortikosteroid seperti budesonid, metilprednisolon, dan prednison, serta golongan asam 5-aminosalisilat seperti mesalasin dan sulfasalasin. Pada umumnya terapi dengan kortikosteroid akan mencapai remisi aktif dalam 8-12 minggu, yang kemudian jika mecapai kondisi remisi akan diikuti dengan penurunan dosis secara bertahap (tappering off). Pada beberapa kondisi berat kortikosteroid dapat diberikan secara parenteral. Pemberian kortikosteroid ditujukan untuk mencapai konsentrasi tertinggi di mukosa usus dengan efek sistemik minimal. Terapi dengan 5-aminosalisilat digunakan untuk mempertahankan kondisi remisi selama mungkin. ${ }^{29}$ Tatalaksana operatif diberikan bila pengobatan konservatif atau farmakologis tidak berhasil dan terdapat komplikasi fistula, perforasi, dan abses. Pada pasien ini termasuk dalam kasus ringan berdasarkan indeks aktivitas penyakitnya serta lokasi lesi yang ada. Pasien direncanakan untuk diterapi dengan mesalasin $500 \mathrm{mg}$ tiap tiga kali sehari.

Prognosis penyakit Crohn tergantung pada kondisi remisi dan komplikasi yang timbul atau tingkat respon terhadap pengobatan konservatif. ${ }^{1}$ Banyak dilaporkan adanya remisi yang bersifat spontan. Risiko keganasan dapat terjadi pada penyakit ini jika aktivitas penyakit tidak dapat dikendalikan. Prognosis dari kasus ini baik karena ketepatan diagnosis dengan endoskopi dan tatalaksana yang baik, sehingga tercapai remisi secara klinis.

\section{SIMPULAN}

Telah dilaporkan suatu kasus penyakit Crohn pada seorang laki-laki berusia 54 tahun. Diagnosis ditegakkan berdasarkan anamnesis, pemeriksaan fisik, pemeriksaan endoskopi dan kolonoskopi, serta pemeriksaan histopatologik.

Pada pasien ini didapatkan buang air besar disertai darah, nyeri perut, mual dan penurunan berat badan. Hasil EGD ialah esofagitis klasifikasi Los Angeles grade A dan gastritis erosiva. Hasil kolonoskopi dengan kesan suspek penyakit Crohn disertai hemoroid interna dan eksterna. Hasil histopatologik mendapatkan gastritis kronik non spesifik, ileitis kronik non spesifik dengan sel datia, pan kolitis non spesifik dan proktitis kronik non spesifik. Aktivitas penyakit diukur dengan skor CDAI sebesar 170 (aktivitas ringan), Berdasarkan klasifikasi Montreal diklasifikasikan sebagai A3 L3 B1 dan SES-CD sebesar 0 (tidak aktif).

Pada pasien ini direncanakan untuk diterapi dengan pemberian mesalasin 500mg tiga kali sehari.

\section{Konflik Kepentingan}

Penulis menyatakan tidak terdapat konflik kepentingan dalam studi ini.

\section{DAFTAR PUSTAKA}

1. Djojoningrat D. Inflammatory bowel disease. In: Siti S, Idrus A, Aru WS, Marcellus SK, Bambang S, Ari FS, editors. Buku Ajar Ilmu Penyakit Dalam Jilid II (6th ed). Jakarta: Pusat Penerbitan Ilmu Penyakit Dalam, 2014; p. 1814-22.

2. Economou M, Zambeli E, Michopoulos S. Incidence and prevalence of Crohn's 
disease and its etiological influences. Ann Gastroenterol. 2009;22(3):158-67.

3. Lelosutan S. Penyakit Crohn. In: Azis R, Marcellus S, Ari FS, editors. Buku Ajar Gastroenterologi (1st ed). Jakarta: Pusat Penerbitan Ilmu Penyakit Dalam, 2011; p. 427-33.

4. Epidemiologi, etiopatogenesis dan gambaran klinis inflammatory bowel disease. In: Konsensus Nasional Penatalaksanaan Inflammatory Bowel Disease di Indonesia. Jakarta, 2011.

5. Zakaria R, Fauzi A, Abdullah M, Syam AF. Diagnostic problems in Chron's disease: a case report. The Indonesian Journal of Gastroenterology, Hepatology, and Digestive Endoscopy. 2011; 12(3):18591.

6. Sartor RB. Mechanism of disease: pathogenesis of Crohn's disease and ulcerative colitis. NCP Gast Hep. 2006; 3(7):390-407.

7. Kim DH, Cheon JH. Pathogenesis of inflamematory bowel disease and recent advances in biologic therapies. Immune Network. 2017;17(1):25-40.

8. Rubin E, Palazzo JP. The gastrointestinal tract. In: Rubin E, Gorstein F, Schwarting R, Strayer DS, editors. Rubin's Pathology: Clinicopathologic Foundations of Medicine (4th ed). Philadelphia: Lippincott Williams \& Wilkins, 2005; p. 713-6.

9. Barret KE. Intestinal mucosal immunology and ecology. Lange Physiology Series, Gastrointestinal Physiology. USA. McGraw-Hill, 2006; p. 115.

10. Talley NJ, Abreu MT, Achkar JP, Bernstein CN, Dubinsky MC, Hanauer SB, et al. An evidence-based systemic review on medical therapies for inflammatory bowel disease. Am J Gastroenterol. 2011;106 (Supp11):S2-25.

11. Nasseri-Moghaddam S. Inflammatory bowel disease. Middle East J Dig Dis 2012; 4(2):77-89.

12. Charles B, Abraham E, Suliman F, Michael F, Richard G, Khean LG, et al. Inflammatory bowel disease. World Gastroenterology Organisation Global Guidelines, 2015

13. Marcus H, Vito A, Stephan RV, Matthieu A, Manuel BA, Kirsten MB, et al. The first European evidence-based consen-sus on extra-intestinal manifestations in inflammatory bowel disease. J Crohns
Colitis. 2016:10(3):239-54.

14. Kim DH, Cheon JH. Pathogenesis of inflammatory bowel disease and recent advances in biologic therapies. Immune Network. 2017;17(1):25-40.

15. Bruce ES, Corey AS. Crohn's Disease. In: Sleisenger and Fordtran's Gastrointestinal and Liver Disease (10th ed). USA: Saunders, 2016; p. 19902022e10.

16. Fernando G, Axel D, Vito A, Herbert T, Gert VA, James OL, et al. The third European evidence-based consensus on the diagnosis and management of Crohn's disease. J Crohns Colitis. 2017;11(1):3-25.

17. Nolan DJ. Radiology of Crohn's disease of the small intestine: a review. Journal of the Royal Society of Medicine. 1981; 74(4):294-300.

18. Lawrence S. Dysmotility of the small intestine and colon. In: Podolsky DK, Camiller M, Fitz JG, Kalloo AN, Shanahan F, Wang TC. Yamada's Textbook of Gastroenterology (6th ed). USA: WileyBlackley, 2016; p. 1190-3.

19. American Society of Gastrointestinal Endoscopy. The role of endoscopy in inflammatory bowel disease. Gastrointest Endosc. 2015; 81(5):1101-21e3.

20. Geboes K. The histopathology of Crohn's disease and ulcerative colitis. Inflammatory Bowel Disease: an Evidence Based. USA: Elsevier, 2001; p. 255-76.

21. Stephanie C, Marcellus S. Management of inflammatory bowel disease. The Indonesian Journal of Gastroenterology, Hepatology, and Digestive Endoscopy. 2014;15(2):111-4.

22. Carter MJ, Lobo AJ, Travis SPL. Guidelines for the management of inflammatory bowel disease in adults. Gut. 2004;53 (Suppl V):v1-16.

23. Yantiss RK, Odze RD. Diagnosis Difficulties in inflammatory bowel disease pathology. Histopathology. 2006;48(2):11632.

24. Geboes K. Pathology of inflammatory bowel disease (IBD): variability with time and treatment. Colorectal Dis. 2001;3(1):212.

25. Bressenot A, Geboes K, Vignaud JM, Gueant JL, Peyrin-Biroulet L. Microscopic features for initial diagnosis and disease activity evaluation in inflammatory bowel disease. Inflamm Bowel Dis. 
16 Medical Scope Journal (MSJ), Volume 2, Nomor 1, Desember 2020, hlm. 7-16

2013;19(8):1745-52.

26. Thad W, Kathryn J, Jigneshkumar P. Diagnosis and management of Crohn's disease.
Am Fam Physician. 2015; 84(12):136575. 